\title{
A Review on Role of Spirituality at Workplace
}

\author{
Sudendra Singh ${ }^{1}$, Dr. Prashant Mishra ${ }^{2}$
}

\section{ABSTRACT}

Spirituality in an organization helps people to do creative work, insightful, the development of rules and overcoming the fear of failures. Results of current studies suggest that spirituality in the organization can play an important role in effectively managing people in the organization. Organizational Spirituality also implies the opportunity to grow and contribute to something substantial. .Spiritual Quotient is a process of insight and personal experience, not a set of beliefs. Spiritual Intelligence is also called "wisdom" or the application of knowledge. There is a purpose for everything and everyone. There is a higher power that affects everything. Spirituality is the feeling that no matter how bad things happen; they will always work out somehow.

Keywords: Spirituality at Work, Wisdom, application of knowledge, Organizational Spirituality, Spiritual Intelligence.

Spirituality is a broad concept with points of view. In general, it includes a sense of belonging to something larger than us, and it usually involves a search for meaning in life. It is a universal human experience, something that affects us all. People can describe a spiritual experience as sacred or transcendent or simply a deep sense of vitality and interconnection. Spirituality is a way of life. How did you experience, how you study, how you live, how you understand, and how you act; called spirituality (Galanter, 2005).

Organizational spirituality is the recognition of an inner life that nurtures and feeds on useful work that takes place in the context of a community (Ashmos and Duchon, 2000). It is about the influence of mental and social aspects of a person to an organizational life, where it is recognized that people are inherently spiritual, and are forced to seek meaning and purpose in all aspects of life, which naturally includes the direction of their work. Spirituality in an organization tends to have certain characteristics, such as the commitment of responsibility, employee involvement in the organization, challenging oneself spiritually. The organization focuses on the virtues, creativity and flexibility. It is willing to hold itself for its values and for the bottom line.

\footnotetext{
${ }^{1}$ Student of BA (Hons.) Applied Psychology, Amity Institute of Behavioural and Allied Science, Amity University Rajasthan, India

${ }^{2}$ Assistant Professor, Amity Institute of Behavioural and Allied Science, Amity University Rajasthan, India *Responding Author

(C) 2016 I S Singh, P Mishra; licensee IJIP. This is an Open Access Research distributed under the terms of the Creative Commons Attribution License (http://creativecommons.org/licenses/by/2.0), which permits unrestricted use, distribution, and reproduction in any Medium, provided the original work is properly cited.
} 


\section{A Review on Role of Spirituality at Workplace}

Spirituality in an organization focuses on the common good rather than focusing on the profit maximization.

\section{Spirituality versus Organization}

Spirituality is now a growing interest in many organizations. Between 1999 and 2001 there had been over 200 articles in management reviews on spirituality and all of them focus on the dimensions of spirituality which involves in different sectors, including social work, health, management, psychology, adult education, etc. (Kale \& Shrivastava, 2003)

Spirituality at work is related to certain factors - inspired leadership, a strong organizational base, organizational integrity, a positive work environment, a sense of community among members, opportunities for personal growth and development, appreciation for employees, etc. At the organizational level, spirituality refers to an organizational culture that is guided by mission statements and by the leadership and business practices that are socially responsible and driven values. Leaders recognize employee contributions made to the organization and implement practices that promote spiritual development and personal well-being. Spiritual needs of the people are the element to develop the motivation and commitment of employees to the organization. The organizational spirituality nourishes the mind, body and soul of its employees.

\section{Need for Spiritual Intelligence}

Spiritual intelligence is used to help people in the company, community, family, etc., to develop their spiritual awareness, ability and intelligence to be more effective as an individual. Spiritual intelligence also plays a very important role in practical life. It extends the ability to understand others at the deepest level. Demanding spiritual understanding also allows both the "real cause" of behavior without judgment, and serves the "real needs" of others. This ability is developed by first learning to free oneself from attachment and neediness and be able to meet their own internal needs. Attachment and poverty are the opposite of being spiritually intelligent. Spiritual Quotient (SQ) unifies, integrates and has the potential to transform the material from the two components: the reason and emotion. Spiritual intelligence facilitates interaction between mind and body, between reason and emotion. It could be less fearful, might be more willing to face the difficulties and could be ready to live in edge between creativity and self-organization based on SQ.

According to Zohar (2000), spiritual intelligence is about the human need and talent to find meaning in the experience. It is one of access to and use of the senses, vision, and value the way we think and the decision is taken. SQ allows us to ask if we want to be in the situation in the first place and it might inspire us to create a new one. Zohar (2004) also concluded that the construction of the spiritual capital, individuals and organizations can become more sustainable. Sustainability depends on building the foundations of collaboration, its life, its organization. If we make transformational change, if we develop the kind of capitalism that has broader concerns, deeper, and values higher purposes, it will not only be sustainable, but we will find it makes more profit. 


\section{REVIEW OF LITERATURE}

Reave (2005) found that spirituality helps the person become crucial leadership that shows respect for others, demonstrate fairness, express care and concern, listen very reactive, and recognize the contributions of others. A study by Dent, Wharff and Higgins (2005) shows that spirituality in an organization contributes to the development of leadership theory. Spirituality is important for business leaders, HR managers, organization members, etc. because it provides a brief understanding of the human self and leading to the development of the company (Burack, 1999).

Kolodinsky, Giacalone and Jurkiewicz (2008) spoke of personal spirituality and the spirituality of the organization. They concluded that spirituality provides the complete satisfaction in the workplace. Vallabh and Singhal (2014) proposed that spirituality helps make the organization a fair place to work and interact with others. Sprung, Silter and Jex (2012) found that spirituality was associated with positive results, except when the workplace aggression was present. In the presence of aggression in the workplace, spiritual employees tend to be more vulnerable to the negative effects than the less spiritual employees. Spirituality at Work shows the relationship between spirituality in the workplace and organizational citizenship behavior, namely the acceptance and take on additional responsibilities, follow the rules and procedures of the organization, maintain and develop a positive attitude, Patience and tolerance in the workplace. (Ahmadi, Nami \& Barvarz 2014)

Kumpikaite (2014) concluded that spirituality at work affects job satisfaction and good performance. Spirituality is linked to performance and efficiency at work. With the help of spirituality, joy of feeling develops in an individual and he / she is a very effective way, resulting in good performance at work (Tischler, Biberman \& McKeage, 2002).

Geroy and Lewis (2000) argue that spiritual beliefs influence the roles in the workplace. Employees manifest spiritual beliefs and practices in the workplace. To prepare future managers for the challenge of managing the spiritual diversity, management educators choose the spirituality of the employee as an intercultural question. Zaidman and Gidoni (2011) also studied spirituality helps improve employee awareness of the work, improve communication and reduce stress. It helps employees know social relationships. They defined the workplace spirituality as a form of organizational wisdom.

Dehaghi, Goodarzi and Arazi (2012) in the study indicated that when employees know spirituality at work, they feel more effectively closed to their organization, experience a sense of responsibility and loyalty to them, and feeling less physically committed. Positive emotions through spirituality can enhance business success. These successes are entrepreneurial in terms of level of creativity and innovation. Spirituality affects the perceptions, attitudes and performance of individuals in the workplace (Raman, Yeow, Eze \& Chin, 2012). 


\section{A Review on Role of Spirituality at Workplace}

Spiritual intelligence enables the individual to face and solve global problems of life while demonstrating virtuous behavior such as humility, compassion, gratitude and wisdom (Emmons \& Shelton, 2002). Emmons (2002) defined the spiritual understanding that the adaptive use of spiritual information to facilitate daily problem solving and achievement of objectives. Intelligence is the implementation of a set of tools to achieve a more productive, efficient, happier, and ultimately more meaningful. Thus, spiritual intelligence is a mechanism by which people can improve their quality of life.

Sass (2000) study extends the academic literature on spirituality in organizations. It is based on a qualitative field research in a nursing home, advanced the understanding of spirituality in organizations by identifying three central characteristics of the spirituality of the organization: alignment of value, personal spirituality and organization based on relationships. These core features, supported by research in the field and of the current literature on spirituality in organizations, lead to problems for further research. The study concluded with an invitation for dialogue on the emerging theme of the spirituality of the organization.

\section{CONCLUSION}

Spiritual intelligence in the organization is the human need and talent to find meaning in life. It is to access the way we think and take the decision by using senses, vision, and beliefs. Spirituality in an organization tend to have certain characteristics, such as the commitment of responsibility, employee participation in the organization, spiritually nourish oneself, spiritual values communication in relationships with others, etc.

After reviewing extensive research, it was concluded that spirituality at workplace helps in developing leadership skills. Spiritual Intelligence helps individual to become a crucial leader who respects other people, express care and concern, and develop listening skills to the appropriate response. It also helps to know the social relationships and wisdom. It affects job satisfaction, performance and helps to develop sense of joy at workplace.

Spirituality is important because it provides a brief understanding of the self and others and leads to the development of the company. It helps to make the organization a fair place to work and improve the quality of interaction with others. Management educators can use the spirituality to prepare managers to face the future challenges in the organization, to improve awareness of employees at work, to improve communication and to reduce stress. Experienced employees with spiritual intelligence feel more connected with organization, have good sense of responsibility and show loyalty towards their work.

In recommendations we can suggest that managers should improve the spiritual intelligence of employees in the organization to promote organizational commitment and organizational performance as positive emotions through spirituality can enhance the level of creativity and innovation of the individual. 


\section{REFERENCES}

Ahmadi, S., Nami, Y. \& Barvarz, R. (2014). The Relationship between Spirituality in the workplace and Organizational Citizenship Behavior. Procedia - Social and Behavioral Sciences. Vol. 114(21), 262-264. Available: www.sciencedirect.com

Ashmos, D. \& Duchon, D. (2000). Spirituality at Work. A Conceptualization and Measure. Journal of Management Inquiry, 9(2), 134-145.

Burack, E. H. (1999). Spirituality in the workplace. Journal of Organizational Change Management. Vol. 12(4), 280-292. Available: www.emeraldinsight.com

Dehaghi, M. R., Goodarzi, M. \& Arazi, Z. K. (2012). The Effect of Spiritual Values o Employees’ Organizational Commitment and Its Models. Procedia - Social and Behavioral Sciences. Vol. 62. 159-166.

Dent, E. B., Higgins, M. E. \& Wharff, D. M. (2005) Spirituality and leadership: An empirical review of definitions, distinctions and embedded assumptions. The Leadership Quarterly. Vol. 16(5), 625-653. Available: www.sciencedirect.com

Emmons, R. A \& Shelton, C. S. (2002). Gratitude and the science of positive psychology. Handbook pf positive psychology, 459-471.

Galanter, M. (2005) Spirituality and the Healthy Mind, Oxford University Press.

Kale, S.H. \& Shrivastava, S. (2003). The Enneagram System for enhancing Workplace Spirituality. Journal of Management Development, 22(4). p.308.

Kolodinsky, R. W., Giacalone, R. A. \& Jurkiewicz, C. L. (2008). Workplace Values and Outcomes: Exploring Personal, Organizational, and Interactive Workplace Spirituality. Journal of Business Ethics. Vol. 81(2), 465-480. Available: link.springer.com

Kumpikaite, V. (2014). Spirituality at Work: Comparison Analysis. Procedia - Social and Behavioral Sciences. Vol. 150. 1205-1212. Available: www.sciencedirect.com

Lewis, J. S. \& Geroy, G. D. (2000). Employee Spirituality in the workplace: A Cross-Cultural View for the Management of Spiritual Employees. Journal of Management Education. Vol. 24(5), 686-694. Available: www.sagepub.com

Raman, K., Yeow, J. A., Eze, U. C., \& Chin, S. T. S. (2012). Relationship Between Emotional Intelligence and Spiritual Intelligence in Nurturing Creativity and Innovation among Successful Entrepreneurs: A Conceptual Framework. Procedia - Social and Behavioral Sciences. Vol. 57. 261-267.

Reave, L. (2005). Spiritual Values and Practices related to leadership effectiveness. The leadership Quarterly. Vol. 16 (5), 655-687. Available: www.sciencedirect.com

Sass, J. S. (2000). Characterizing organizational Spirituality: An organizational communication culture approach, Communication Studies, Vol. 51(3). 195-217.

Sprung, J. M., Sliter, M. T. \& Jex, S. M. (2012) Spirituality as a moderator of the relationship between workplace aggression and employee outcomes. Personality and Individual Differences. Vol. 53(7), 930-934. Available: www.sciencedirect.com

Tischler, L., Biberman, J. \& McKeage, R. (2002). Linking emotional Intelligence, Spirituality and Workplace performance: Definitions, modes and ideas for research. Journal of Managerial Psychology. Vol. 17(3), 203-218. Available: www.emeraldinsight.com 


\section{A Review on Role of Spirituality at Workplace}

Zaidman, N. \& Gidoni, O. G. (2011). Spirituality as a discarded form of organizational wisdom: Field-based analysis. Group \& Organizational Management,36(5), 630-653.

Zohar, D and Marshall, I. (2004). Spiritual Capital: Wealth we can live by. BK Publisher: San Francisco.

Zohar, Danah \& Ian Marshall. (2000). SQ: Spiritual Intelligence, the Ultimate Intelligence, Bloomsbury Press, New York.

How to cite this article: S Singh, P Mishra (2016), A Review on Role of Spirituality at Workplace, International Journal of Indian Psychology, Volume 3, Issue 3, No. 8, DIP: 18.01.152/20160303, ISBN: 978-1-365-12176-0 